\title{
Endophytic Bacillus spp. as a Prospective Biological Tool for Control of Viral Diseases and Non-vector Leptinotarsa decemlineata Say. in Solanum tuberosum L.
}

\section{OPEN ACCESS}

Edited by:

Prem Lal Kashyap,

Indian Institute of Wheat and Barley

Research (ICAR), India

Reviewed by:

Mathuresh Singh,

Agricultural Certification Services Inc.

(ACS), Canada

Vera Ulyanova,

Kazan Federal University, Russia

*Correspondence:

Igor Maksimov

igor.mak2011@yandex.ru; maksimov@ufaras.ru

Specialty section: This article was submitted to

Microbial Symbioses,

a section of the journal

Frontiers in Microbiology

Received: 04 June 2020 Accepted: 10 September 2020

Published: 15 October 2020

Citation:

Sorokan A, Cherepanova E, Burkhanova G, Veselova S,

Rumyantsev S, Alekseev V,

Mardanshin I, Sarvarova E, Khairullin R, Benkovskaya $G$ and

Maksimov I (2020) Endophytic

Bacillus spp. as a Prospective Biological Tool for Control of Viral

Diseases and Non-vector Leptinotarsa decemlineata Say.

in Solanum tuberosum L.

Front. Microbiol. 11:569457. doi: 10.3389/fmicb.2020.569457
Antonina Sorokan', Ekaterina Cherepanova', Guzel Burkhanova', Svetlana Veselova', Sergey Rumyantsev², Valentin Alekseev ${ }^{1}$, Ildar Mardanshin ${ }^{3}$, Elena Sarvarova ${ }^{2}$, Ramil Khairullin', Galina Benkovskaya ${ }^{4}$ and Igor Maksimov ${ }^{1 *}$

1 Laboratory of Biochemistry of Plant Immunity, Institute of Biochemistry and Genetics, Ufa Federal Research Center, Russian Academy of Sciences, Ufa, Russia, ${ }^{2}$ Laboratory of Genomics of Plants, Ufa Federal Research Center, Institute of Biochemistry and Genetics, Russian Academy of Sciences, Ufa, Russia, ${ }^{3}$ Laboratory of Selection and Seed Production of Potato, Bashkir Research Institute of Agriculture, Ufa Federal Research Center, Russian Academy of Sciences, Ufa, Russia, ${ }^{4}$ Laboratory of Physiological Genetics, Institute of Biochemistry and Genetics, Ufa Federal Research Center, Russian Academy of Sciences, Ufa, Russia

Viral diseases and their damage causing significant loss to economically important crops have increased by several folds during the last decade. All the conventional approaches are not able to eradicate the viral infection. Therefore, there is a need to look for efficient and eco-friendly viral disease-preventive measures. The genomic material of the majority of deleterious viruses of higher plants is RNA. One of the possible measures to control viruses is the use of ribonucleases (RNases), which can cleave RNA in the viral genome. Based on this, we investigated the RNase activity of endophytic Bacillus spp., which can enrich in $10^{3}-10^{5}$ colony-forming units per gram of wet mass of aboveground part of potato plants. A high level of RNase activity was observed in the culture medium of Bacillus thuringiensis B-6066, Bacillus sp. STL-7, Bacillus sp. TS2, and Bacillus subtilis 26D. B. thuringiensis B-5351 had low RNase activity but high ability to colonize internal plant tissues, Bacillus sp. STL-7 with high RNase activity have relatively low number of cells in internal tissues of plants. B. thuringiensis B-6066, B. subtilis 26D, and Bacillus sp. TS stimulate RNase activity in potato plants for a long time after application. Strains with high ability to colonize internal plant tissues combined with high RNase activity reduced severity of viral diseases symptoms on plants and reduced the incidence of potato viruses M, S, and Y. It is worth noting that Bacillus spp. under investigation reduced the number of Leptinotarsa decemlineata Say. egg clusters and larvae on treated plants and showed antifeedant activity. This results in increase of potato productivity mainly in the fraction of major tubers. B. subtilis 26D and Bacillus sp. TS2 combining endophytic lifestyle, RNase, and antifeedant activity may become the basis for the development of biocontrol agents for plant protection.

Keywords: Solanum tuberosum, viruses, endophyte, Bacillus, RNases 


\section{INTRODUCTION}

Viruses cause epiphytoties among all agricultural crops worldwide. This threatens food security and stability of crop yields in a number of regions. The development of efficient and durable resistance able to withstand viral attacks represents a major challenge for agrobiology. For instance, cultivated plants are affected by at least 450 different viruses (Soosaar et al., 2005), more than 40 of them infect potato plants (Solanum tuberosum L.), significantly reducing their productivity and deteriorating the quality of tubers (Makarova et al., 2017), which is known as the cultivar degeneration. The most common and important viruses of potato are potato leaf roll virus (PLRV), potato virus Y (PVY), potato virus A (PVA), potato virus X (PVX), potato virus $\mathrm{S}$ (PVS), and potato virus M (PVM). Currently, viruses cannot be controlled with chemical pesticides, since known antiviral compounds such as teratogenic ribavirin $(1, \beta-$ D-ribofuranosyl-1,2,4-triazole-3-carboxamide) are hazardous to people's health (De Fazio et al., 1980). Considering that viruses have more than one species of plant host and that several unrelated viruses can infect plants simultaneously, it is important that more than one virus can be found within the same plant and can damage crops to a greater degree (Moreno and López-Moya, 2020). Thus, PVY is the most important viral pathogen in the world. PVY caused major economic damage to potato production worldwide (Alyokhin et al., 2008). In contrast to vector-borne viruses, PVY can be transmitted both non-persistently by aphids and mechanically through contact with infected plants. Thus, insecticides are an inadequate method of PVY control (Hussain et al., 2016). At the moment, PVY rapidly evolving and an increasing number of strains in PVY-complex evade many certification practices (based on PCR or immunoassay analysis) and defense measures. Seed certification programs often cannot be effective at managing PVY below economic thresholds as a consequence of its variability (Gray and Power, 2018). Yield losses caused by PVS and PVM are usually less than 10-20\%, but co-infections of PVY and PVS and/or PVM amplify PVY caused losses (Pruss et al., 1997). Unfortunately, the latter is common in potatoes in many regions.

Non-vector herbivores, such as the most harmful pest Colorado potato beetle (CPB; Leptinotarsa decemlineata Say.) can mechanically transfer potato viruses. Diverse life cycle, ecological mobility, symbiosis with bacterial species (Sorokan et al., 2019), and high adaptability to a broad spectrum of stressors, including pesticides, allow $\mathrm{CPB}$ to spread almost everywhere (Alyokhin et al., 2008). Control of CPB is a difficult task since the pest becomes resistant to pesticides. Increased growth of CPB larvae, which propagated on PVYinfected plants in comparison with uninfected plants, was reported previously (Kersch-Becker and Thaler, 2014; Petek et al., 2014). Non-vectored tobacco mosaic virus (TMV) improved the survival of CPB larvae and adults, possibly, due to the

Abbreviations: BTB, Bitoksibacilline; CFU, colony-forming units; CPB, Colorado potato beetle; LB, lysogeny broth; LP, low phosphorus medium; PGPB, plant growth-promoting bacteria; PVM, potato virus M; PVS, potato virus S; PVY, potato virus $\mathrm{Y}$. increased nitrogen content in TMV-infected plants (Hare and Dodds, 1987). CPB female adults tended to feed on PLRVinfected potato foliage, although these individuals had lower fecundity and shorter longevity when fed virus-infected foliage in comparison with the ones that ate uninfected foliage (Boiteau and Singh, 1982). On the one hand, enhanced CPB larval growth of the ones reared on PVY-infected plants can be explained by inhibited accumulation of products of defense genes, such as proteinase inhibitors, associated with antifeedant properties of potato (Petek et al., 2014). On the other hand, colonization of PVY-infected plants, which had decreased growth, nutritional quality, and ability to regenerate damage caused by beetles, involves certain risks. Booth and Alyokhin (2016) suggested that there may be the strong selection pressure for choosing PVY-uninfected plants. Kersch-Becker and Thaler (2014) showed that the performance of non-vector herbivores Trichoplusia $n i$ and L. decemlineata positively correlated with the strength of salicylate induction in tomato plants under the influence of PVY.

Thus, plants are exposed to various harmful organisms simultaneously. In this regard, plant protection requires an evergrowing volume of chemical pesticides annually. Unregulated control measures lead to escalation of anthropogenic negative impact on the environment. In addition, arising pathogens and pests resistant to chemicals overcomes protection measures. The search of environmentally safe biocontrol agents, based on beneficent microorganisms that combine diversified biocidal activities against common pathogens and pests and ability to prime immune reactions in plants via stimulation of specific signaling cascades, is of great interest. Some of the beneficial and heterogeneous group plant growth-promoting bacteria (PGPB) able to exist in internal plant tissues and called "endophytes" have drawn increasingly greater attention from researchers and manufacturers of biocontrol agents and biofertilizers (Li et al., 2015; Mishra et al., 2015; Maksimov et al., 2018). Bacterial endophytes have an advantage over bacteria inhabiting the rhizo- or phyllosphere, since living within a plant's tissues represents an opportunity to be in constant "contact" with the plant's cells, and endophytes become more integrated in plant metabolism than rhyzo- and phyllospheric microorganisms. PGPB strains show fungicidal (Aydi Ben Abdallah et al., 2016), insecticidal (Sorokan et al., 2016; Yang et al., 2017), and growth-promoting activities (Sansinenea, 2019); synthesize antibiotics and biosurfactants (Maksimov et al., 2020); and induce systemic resistance in plants against pathogens and pests (Rashid and Chung, 2017). The entomopathogenic capacity of Bacillus thuringiensis strains to different orders of pests (Diptera, Lepidoptera, Hymenoptera, Coleoptera, Orthoptera, Hemiptera, etc.) involves synthesizing crystalline proteins that have insecticidal activity when ingested by a susceptible host (Domínguez-Arrizabalaga et al., 2019), and now the ability of B. thuringiensis strains to invade plant internal tissues is of great interest, as well as insectotoxic properties of endophytic Bacillus subtilis strains.

These diverse effects allow the use of PGPB for protection against multiple environmental factors. Thus, B. thuringiensis strains can be applied to protect tea plants 
from both insect and mite pests (Idris et al., 2020). The multifunctional protective effect of endophytic strain $B$. subtilis 26DCry expressing insectotoxic Cry1Ia protein and surfactin against both aphids and pathogens on wheat plants was shown previously (Maksimov et al., 2020). It also should be noted that Bouizgarne (2012) assumed data on plant protection and suggested that in some cases the treatment of plants with endophytes was more advantageous than the cultivation of transgenic plant varieties resistant to viruses. Implementing manufactured plant microbiomes with PGPB that are capable to release antiviral compounds in plants and to prime mechanisms of plant resistance to viral pathogens can become a challenging alternative to chemical pesticides and transgenic plants (Maksimov et al., 2019).

Secretion of enzymes including RNases, which participate in mobilization of organic phosphates, is one of the mechanisms of bacterial adaptation to changing environmental conditions. The ability of Bacillus pumilus, Bacillus amyloliquefaciens, and Bacillus licheniformis to produce extracellular RNases (binases, baRNases, and baliphases, respectively) is actively investigated (Ulyanova et al., 2016; Ilinskaya et al., 2018). Low concentrations of RNases stimulate plant growth and resistance to a broad spectrum of stress factors, and high levels of them show antiviral properties by destroying viral RNA. Thus, all Pantoea, Cronobacter, Microbacterium, and Staphylococcus isolates, which originate from Cucurbitaceae plants produce nucleases, as well as $73 \%$ of Bacillus, $30 \%$ of Enterobacteriaceae, and $27 \%$ of Paenibacillus isolates (Khalaf and Raizada, 2018). Pseudomonas putida A3 (Yang et al., 2012) and B. pumilus 7P/3-19 (Sharipova et al., 2015) were shown to cleave viral particles in the juice from TMV-infected tobacco plants. The strong positive correlation was shown between the RNase activity in different potato varieties and their resistance to PVX, PVY, PVM, and PVS (Trifonova et al., 2018). Expression of RNase gene PAC1 from Schizosaccharomyces pombe in soybean plants led to a significantly higher level of uninfected with prevalent in soybeangrowing regions of China soybean mosaic virus (SMV) SC3 strain under the field conditions, compared with the areas where non-transformed plants were grown (Yang et al., 2019). Plants of Nicotiana benthamiana containing genetically engineered CRISPR/Cas13a cassette that included class 2 type VI-A RNase capable to recognize and cleave single-stranded RNA were highly resistant to turnip mosaic virus (TuMV) (Aman et al., 2018). Complete resistance to tomato leaf curl virus infection was shown in one third of the transgenic tobacco clones expressing baRNase gene from B. amyloliquefaciens (PakniatJahromy et al., 2010). The data shown above tend to favor the view that Bacillus can protect plants against viral diseases by affecting phytopathogens, nematodes, and insects, which are vectors of viral particles. At the same time, endophytic Bacillus producing RNases can cleave viral particles directly in plant tissues.

In this context, the aim of our work was the investigation of the influence of endophytic RNase-producing Bacillus spp. strains on viral and insect spread and potato productivity under the field conditions.

\section{MATERIALS AND METHODS}

\section{Bacterial Strains}

Bacterial strains Bacillus subtilis 26D, Bacillus thuringiensis var. thuringiensis B-5689, B. subtilis $11 \mathrm{VM}$, B. thuringiensis var. kurstaki B-535, and B. thuringiensis var. kurstaki B-6066 were provided by the limited liability company Bashincom (Russia). Isolates B. sp. STL7 and Enterobacter sp. BC-8 were obtained from surface-sterilized intact and $\mathrm{CPB}$-damaged potato leaves, respectively. Bacillus sp. TS2 was obtained from surfacesterilized leaves of Triticum aestivum L. All isolates were collected from plants that were grown on the territory of Iglinsky District $\left(54^{\circ} 50.48^{\prime} 94.0^{\prime \prime} \mathrm{N} ; 56^{\circ} 26.46^{\prime} 09.0^{\prime \prime} \mathrm{E}\right)$ of the Republic of Bashkortostan (Russia). All isolates are held in the collection of the Laboratory of Biochemistry of Plant Immunity, Institute of Biochemistry and Genetics, Ufa Federal Research Center RAS ${ }^{1}$.

Selected isolates were characterized through its biochemical and physiological properties according to Bergey's Manual of Systematic Bacteriology (Table 1). Biocontrol agent Bitoksibacilline (BTB) (Sibbiopharm, Russia) on the base of B. thuringiensis var. thuringiensis $\mathrm{BtH}_{1} 98$ was used as a positive control. Sequencing of $16 \mathrm{~S}$ RNA gene fragments of isolates Bacillus sp. STL7 (GenBank: MT613864), Bacillus sp. TS2 (GenBank: MT605808), and Enterobacter hormaechei BC-8 (GenBank: MT605809) was carried out using NovaSeq 6000 Sequencing System (Illumina, United States), with NovaSeq 6000 SP Reagent Kits (Illumina, United States). Nucleotide sequence analysis was presented by using international GenBank database. Bacterial culture was cultivated on lysogeny broth (LB) basal medium $(0.5 \mathrm{~g} / \mathrm{L}$ of $\mathrm{NaCl})$ in $\mathrm{TC} 1 / 20$ chamber (SPU, Russia) at a temperature $28^{\circ} \mathrm{C}$. Sixteen-hour cultures were used for endophytic properties, antiviral activity, and influence on potato productivity estimation.

\section{Estimation of Ribonuclease Activity}

Quantitative estimation of extracellular RNase activity in liquid culture medium was carried out according to the modified method of Sokurenko et al. (2016). Bacteria strains and isolates were grown on LP medium (low phosphate peptone, 2\%; glucose, $1 \%$; $\mathrm{Na}_{2} \mathrm{HPO}_{4}, 0.04 \% ; \mathrm{CaCl}_{2}, 0.01 \% ; \mathrm{MgSO}_{4}{ }^{*} 7 \mathrm{H}_{2} \mathrm{O}$, $0.03 \% ; \mathrm{MnSO}_{4}, 0.01 \% ; \mathrm{NaCl}, 0.3 \%, 120 \mu \mathrm{g} / \mathrm{ml}$ of phosphorus). Bacteria were cultivated at $37^{\circ} \mathrm{N}$ using a laboratory shaker ES20 with oscillation intensity of $120 \mathrm{rpm}$ (Biosan, Lithuania). Culture growth was measured spectrophotometrically at $590 \mathrm{~nm}$ and expressed as optical density units (OD590). When density of bacteria reached $10^{8}$ cells/ml cultures were centrifuged for $15 \mathrm{~min}$ at $8,000 \mathrm{~g}$ in a $5415 \mathrm{R}$ centrifuge (Eppendorf, Germany). Potato leaves were homogenized in sterile bags in $1 \mathrm{ml}$ of $0.05 \mathrm{M}$ tris- $\mathrm{HCl}$ buffer ( $\mathrm{pH}$ 8.5) using blender BagMixer 400W (Interscience, France) and incubated for $60 \mathrm{~min}$ at $4^{\circ} \mathrm{C}$. The homogenates were spun off for $15 \mathrm{~min}$ at $8,000 \mathrm{~g}$ in a $5415 \mathrm{R}$ centrifuge (Eppendorf, Germany). pH meter HI 83141 (Hanna Instruments, Romania) was used for $\mathrm{pH}$ measurement. Twenty microliters of the homogenates was added to $1.98 \mathrm{ml}$ of 50 $\mu \mathrm{g} / \mathrm{ml}$ of torula yeast RNA solution in $0.05 \mathrm{M}$ of tris- $\mathrm{HCl}$

\footnotetext{
${ }^{1}$ http://ibg.anrb.ru/wp-content/uploads/2019/04/Katalog-endofit.doc
} 
TABLE 1 | Biochemical and morphological characterization of bacterial isolates.

\begin{tabular}{|c|c|c|c|}
\hline Properties & Bacillus sp. TS2 & $\begin{array}{l}\text { Bacillus sp. } \\
\text { STL7 }\end{array}$ & $\begin{array}{c}\text { Enterobacter } \\
\text { sp. BC-8 }\end{array}$ \\
\hline Plant & Triticum aestivum & $\begin{array}{l}\text { Solanum } \\
\text { tuberosum }\end{array}$ & S. tuberosum \\
\hline Organ & Stem & Leaves & Leaves \\
\hline Cell morphology & Rod & Rod & Rod \\
\hline Gram's reaction & + & + & - \\
\hline Spore forming & + & + & - \\
\hline Grow at $4^{\circ} \mathrm{C}$ & - & - & - \\
\hline Grow at $50^{\circ} \mathrm{C}$ & - & - & - \\
\hline Grow at $60^{\circ} \mathrm{C}$ & - & - & - \\
\hline $\begin{array}{l}\text { Anaerobic } \\
\text { conditions }\end{array}$ & - & - & + \\
\hline Amylase & + & + & - \\
\hline Protease & + & + & + \\
\hline Gelatinase & + & - & - \\
\hline Lipase & + & - & - \\
\hline Catalase & + & + & + \\
\hline RNase & + & + & - \\
\hline $\begin{array}{l}\text { Acid from } \\
\text { glucose }\end{array}$ & + & + & + \\
\hline Gas from glucose & - & - & + \\
\hline $\begin{array}{l}\text { Acid from } \\
\text { sacharose }\end{array}$ & + & + & + \\
\hline $\begin{array}{l}\text { Acid from } \\
\text { mannitol }\end{array}$ & + & + & + \\
\hline Acid from lactose & - & + & - \\
\hline $\begin{array}{l}\text { Growth on } \\
\text { Simmons's } \\
\text { medium (citrate) }\end{array}$ & + & + & + \\
\hline Urea hydrolysis & + & - & - \\
\hline Voges-Proskauer & + & + & + \\
\hline $\mathrm{NH}_{3}$ production & - & - & + \\
\hline Indole production & - & - & - \\
\hline $\mathrm{H}_{2} \mathrm{~S}$ production & - & - & - \\
\hline Pigment & - & - & - \\
\hline
\end{tabular}

buffer ( $\mathrm{pH}$ 8.5) (Sigma, United States) and kept at $25^{\circ} \mathrm{C}$ for $1 \mathrm{~h}$, and its absorbance was measured at $260 \mathrm{~nm}$ relative to the control (mixture reaction without leaf extract or bacterial medium) at $260 \mathrm{~nm}$ on an LLG-uniSPEC 2 spectrophotometer (LLG, Germany). The unit of nuclease activity was taken as the amount of enzyme causing an increase in adsorption by 1.0 optical unit at $260 \mathrm{~nm}$ for $1 \mathrm{~h}$ at $25^{\circ} \mathrm{C}$ (Ilinskaya et al., 1996). RNase activity was expressed as units/min.ml of liquid medium (extracellular Bacillus RNase activity) or units/min·mg of protein (RNase activity in plants). Protein concentration in plants was measured using Bradford assay.

\section{Endophytic Properties}

Endophytic content of the tested strains was evaluated by counting the colony-forming units (CFU) of microorganisms in plant tissues 7 days after inoculation of sterile test tube potato plants (Udacha variety) cultivated for 25 days at $16 \mathrm{~h}$ illumination (Osram L 36W/77 lamps, Germany) in the KS200 climate chamber (SPU, Russia) on the agarose Murashige-Skoog medium. At least 20 plants were inoculated with $5 \mathrm{ml}$ of each strain (or isolate) suspension $\left(10^{8}\right.$ cells $\left./ \mathrm{ml}\right)$, which were grown on LB medium. For CFU estimation, $100 \mathrm{mg}$ samples of each individual experimental plant were superficially sterilized in the following order: $70 \%$ ethanol ( $1 \mathrm{~min}) \rightarrow 0.1 \%$ diacide1 (3 min) $\rightarrow$ distilled water. The samples were homogenized in sterile bags using BagMixer $400 \mathrm{~W}$ blender (Interscience, France) with $2 \mathrm{ml}$ of sterile water added. Two consecutive 10fold dilutions of the resultant homogenate were then performed. Aliquots $(100 \mu \mathrm{l})$ were spread over the surface of potato-glucose agar by a microbiological loop until complete drying. Petri dishes were then incubated at $28^{\circ} \mathrm{C}$ in the TS-1/20 SPU thermostat (Smolensk SKTB SPU, Russia) for $24 \mathrm{~h}$. CFU were counted in the second and third dilutions, and their number was recalculated per $1 \mathrm{~g}$ of plant wet weight.

\section{Field Experiment Design}

The study was carried out at the experimental fields of Ufa Federal Science Center RAS (Birsk Experimental Station, 55 $25^{\prime} 47.4^{\prime \prime} \mathrm{N}$ $55^{\circ} 35^{\prime} 49.9^{\prime \prime} \mathrm{E}$ ) during the 2019 and 2020 cropping seasons. There was relatively high temperature at the beginning of the growth season in 2019 and 2020 (Table 2). In 2020, there was a high mean monthly temperature in July compared with the long-term average $^{2}$. An average for 2 years' data is presented in the figures.

Fields were located on gray forest soils (northern forest steppe). The soils were not water logged, and the texture was sandy loam. The humus content was $3.5-4.0 \%$, and $\mathrm{pH}$ of soil was 5.5-6.5. Potato rotation system included wheat and triticale. Seed tubers (elite grade, state standard 33996-201) of the original Udacha variety under study were provided by the Branch of the Federal State Institution "Rosselkhoztsentr" in the Republic of Bashkortostan [certificates 104105 E1 0115-19 (2019 year), 002 001 E1 0454-20 (2020 year)]. The presence of PVY, PVS, and PVM was not detected.

Tubers were planted at $5 \mathrm{~cm}$ depth in rows with $75 \mathrm{~cm}$ distance; the interval between tubers in a row was about $30 \mathrm{~cm}$. The planting density was 45,000 tubers per ha. Planting time was the 13th of May. Grimme GL 34T (GRIMME-Rus, Russia) seeding machine was used. The speed of planting was $3 \mathrm{~km} / \mathrm{ha}$. Tubers were planted in three repeats of 40 plants per plot for each variant. Three plots were used as replicates for each treatment as well as for the untreated control treatment (water spraying). Two-week seedlings were sprayed with different strains of Bacillus suspensions ( $10^{6}$ cells/plant) or BTB (50 g/10 L

\footnotetext{
${ }^{2}$ http://weatherarchive.ru/Temperature/Birsk/
}

TABLE 2 | Temperature regime in 2019-2020 cropping seasons.

\begin{tabular}{lccc}
\hline & \multicolumn{3}{c}{ Mean monthly temperature, ${ }^{\circ} \mathbf{C}$} \\
\cline { 2 - 4 } & May & June & July \\
\hline 2019 & 14.91 & 17.39 & 18.05 \\
2020 & 13.87 & 15.83 & 20.1 \\
Average (2004-2019) & 13.3 & 16.7 & 18.5
\end{tabular}


of water, $100 \mathrm{ml} /$ plant). The concentration of the inoculum was determined spectrophotometrically at $600 \mathrm{~nm}$ on BioSpec-Mini spectrophotometer (Shimadzu, Japan). Spraying was duplicated after flowering in the same manner.

We observed the density of CPB population on $0,7,17$, and 31 days in 2019 after the first treatment and on $0,8,17$, and 29 days after the first treatment in 2020. Season average number (data pooled over the experimental period) ( \pm SE) of $\mathrm{CPB}$ egg clusters, early instar larvae (L1 + L2), and last instar larvae (L3 + L4) per plant according to different treatments in 2019-2020 was counted. Defoliation caused by CPB was visually evaluated based on a percentage ranking system; 100\% corresponds to complete defoliation, and 0 represents no feeding damage on the 31st day after treatment. Leaves of 30 plants per variant were tested on virus presence and RNase activity on the 17th [distributional of immunofluorescence assay (IFA)detected viral particles in plants was found to be statistically significant, but visual symptoms of diseases were sporadic] and the 31st day (2019) or 29th day (2020) after the first treatment (visual symptoms became significant on all treated plots). Plants adjacent to free spaces between plots were not examined to avoid edge effect.

Potato tubers were harvested on the 65th (2019 year) and 60th (2020 year) days after the first treatment. On the day of harvest, the tubers were classified into three fractions-small (tubers $<50 \mathrm{~g}$ ), seed (tubers between 50 and $80 \mathrm{~g}$ ), and large (tubers $>80 \mathrm{~g}$ )-and weighed separately. Data on the productivity of potatoes were prepared according to Bakhvalova et al. (2015).

\section{Double Antibody Sandwich-ELISA}

Direct double antibody sandwich (DAS) ELISA was used with PVM, PVS, and PVY DAS-ELISA Complete kits (Bioreba, Switzerland). Specific rabbit IgG was diluted 1:1,000 in the coating buffer; $200 \mu \mathrm{l}$ of diluted IgG to each well of Nunc MaxiSorp F96 microtiter plates was pipetted and stored at $4^{\circ} \mathrm{C}$ overnight. Leaf samples were homogenized in the extraction buffer "General" (DAS-ELISA Complete kits, Bioreba, Switzerland) at a ratio of $1: 20(\mathrm{w} / \mathrm{v}) ; 200 \mu \mathrm{l}$ of the plant extract was added to each well and incubated for $16 \mathrm{~h}$ at $4^{\circ} \mathrm{C}$. Conjugate of rabbit IgG (anti-potato viruses) with alkaline phosphatase 1:1,000 in conjugate buffer was added and incubated at $30^{\circ} \mathrm{C}$ for $5 \mathrm{~h}$; after this, $200 \mu \mathrm{l}$ of the substrate pNPP (para-nitrophenylphosphate) in substrate buffer $\mathrm{pH} 9.8$ (DASELISA Complete kits, Bioreba, Switzerland) $(1 \mathrm{mg} / \mathrm{ml})$ were added. After $30 \mathrm{~min}\left(20-25^{\circ} \mathrm{C}\right.$ in the dark), optical density was measured at $405 / 492 \mathrm{~nm}$ on plate reader Uniplan AIFR-01 (CJSC Picon, Russia).

\section{Statistics}

Laboratory experiments were repeated three times in three replications. Mean values with standard errors $( \pm S E)$ are given in the figures and tables. Statistical analyses were carried out using Microsoft Excel 2013 for Windows (Microsoft Corporation, United States) and IBM SPSS Statistics 2.0 (IBM Corporation, United States). Differences in parameters under investigation between individual treatments were analyzed with the use of ANOVA. Prior to analysis, each variable was tested for homogeneity of variance, and the data found to be nonhomogenous were transformed to $\log (\mathrm{Y})$ before ANOVA. Significant differences $(P \leq 0.05)$ between mean values were identified using Tukey's honestly significant difference (HSD) multiple-range test. Different letters on figures label significant differences between treatments according to Tukey's HSD multiple-range test at $P<0.05$. Pearson's correlation coefficient was used to understand the nature of relationships between individual parameters.

\section{RESULTS}

\section{Endophytic Properties and Ribonuclease Activity of Bacillus Strains}

We showed the presence of RNase activity in all Bacillus strains and isolates under investigation (Table 3). Isolated from CPBdamaged potato leaves, Enterobacter sp. BC-8 did not express any RNase activity. The significant RNase activity was observed in the liquid culture medium of Bacillus thuringiensis B-6066, Bacillus sp. STL-7, Bacillus sp. TS2 and Bacillus subtilis 26D, and B. thuringiensis B-5689 and minimally in the culture medium of B. thuringiensis B-5351.

TABLE 3 | RNase activity of bacterial strains in vitro and its CFU content in internal tissues of potato stems.

\begin{tabular}{|c|c|c|c|c|c|c|c|c|}
\hline $\begin{array}{l}\text { Variant/ } \\
\text { parameter }\end{array}$ & $\begin{array}{c}\text { Bacillus sp. } \\
\text { TS2 }\end{array}$ & $\begin{array}{l}\text { Bacillus sp. } \\
\text { STL7 }\end{array}$ & $\begin{array}{c}\text { Bacillus } \\
\text { thuringiensis } \\
\text { B-6066 }\end{array}$ & $\begin{array}{c}\text { Bacillus } \\
\text { subtilis } \\
11 \mathrm{VM}\end{array}$ & $\begin{array}{c}\text { B. subtilis } \\
\text { 26D }\end{array}$ & $\begin{array}{c}\text { B. thuringiensis } \\
\text { B-5351 }\end{array}$ & $\begin{array}{c}\text { Enterobacter } \\
\text { sp. BC-8 }\end{array}$ & $\begin{array}{c}\text { B. thuringiensis } \\
\text { B-5689 }\end{array}$ \\
\hline $\begin{array}{l}\text { RNase, } \\
\text { OD/min.ml of } \\
\text { culture medium }\end{array}$ & $6.45 \pm 1.03 a$ & $5.87 \pm 0.96 a$ & $6.02 \pm 0.86 a$ & $3.04 \pm 0.55 b$ & $3.97 \pm 0.77 a$ & $1.32 \pm 0.08 c$ & Od & $2.64 \pm 0.04 b$ \\
\hline $\begin{array}{l}\text { Endophyticity, } \\
\mathrm{CFU}{ }^{*} 10^{3} / \mathrm{g} \text { of } \\
\text { wet mass }\end{array}$ & $120.0 \pm 14.2 \mathrm{a}$ & $3.5 \pm 0.1 b$ & $90.0 \pm 13.4 c$ & $90.0 \pm 12.3 c$ & $350.0 \pm 15.6 d$ & $70.0 \pm 12.3 c$ & $0.01 \pm 0.001 e$ & $3.0 \pm 0.11 b$ \\
\hline
\end{tabular}

-, none detected.

Data represented as mean values \pm standard error;

Values followed by the same alphabet within a row are not significantly different from each other by Tukey HSD test $P<0.05$.

CFU, colony-forming units; HSD, honestly significant difference. 


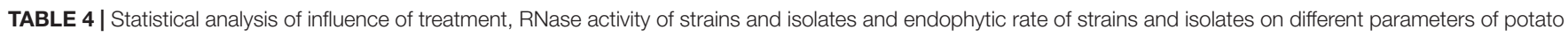
plants under the field conditions.

\begin{tabular}{|c|c|c|c|c|c|c|c|}
\hline Early period & $\boldsymbol{F}$ & $d f$ & $\boldsymbol{P}$ & Latest period & $\boldsymbol{F}$ & $d f$ & $P$ \\
\hline \multicolumn{8}{|l|}{ Treatment } \\
\hline RNase activity in plants & 6.78 & 9,590 & $<0.05$ & RNase activity in plants & 5.07 & 9,590 & $<0.05$ \\
\hline Eggs per plant & 6.88 & 9,590 & $<0.05$ & & & & \\
\hline \multirow[t]{2}{*}{ Young instar larvae per plant } & 14.07 & 9,590 & $<0.05$ & Last instar larvae per plant & 4.97 & 9,590 & $<0.05$ \\
\hline & & & & Consumed leaves per plant & 4.86 & 9,590 & $<0.05$ \\
\hline PVY infected plants per plot & 4.67 & 9,50 & $<0.05$ & PVY infected plants per plot & 6.84 & 9,50 & $<0.05$ \\
\hline PVS infected plants per plot & 5.08 & 9,50 & $<0.05$ & PVS infected plants per plot & 4.95 & 9,50 & $<0.05$ \\
\hline PVM infected plants per plot & 4.86 & 9,50 & $<0.05$ & PVM infected plants per plot & 12.75 & 9,50 & $<0.05$ \\
\hline PVY + PVM infected plants per plot & 7.25 & 9,50 & $<0.05$ & PVY + PVM infected plants per plot & 6.84 & 9,50 & $<0.05$ \\
\hline PVY + PVS infected plants per plot & 5.43 & 9,50 & $<0.05$ & PVY + PVS infected plants per plot & 6.36 & 9,50 & $<0.05$ \\
\hline \multirow[t]{6}{*}{ PVM + PVS infected plants per plot } & 8.43 & 9,50 & $<0.05$ & PVM + PVS infected plants per plot & 4.81 & 9,50 & $<0.05$ \\
\hline & & & & Viral symptoms per plant & 5.34 & 9,290 & $<0.05$ \\
\hline & & & & Total weight & 7.95 & 9,50 & $<0.05$ \\
\hline & & & & Weight of tubers in fraction $=80 \mathrm{~g}$ & 8.65 & 9,50 & $<0.05$ \\
\hline & & & & Weight of tubers in fraction $=50 \mathrm{~g}$ & 4.32 & 9,50 & $>0.05$ \\
\hline & & & & Weight of tubers in fraction $<50 \mathrm{~g}$ & 4.44 & 9,50 & $<0.05$ \\
\hline \multicolumn{8}{|l|}{ RNase activity in culture medium } \\
\hline Endophytic properties of bacteria & 2.04 & 3,298 & $>0.05$ & & & & \\
\hline RNase activity in plants & 9.07 & 3,598 & $<0.05$ & RNase activity in plants & 4.01 & 3,598 & $>0.05$ \\
\hline Eggs & 3.87 & 3,598 & $>0.05$ & & & & \\
\hline \multirow[t]{2}{*}{ Young instar larvae } & 7.84 & 3,598 & $>0.05$ & Last instar larvae & 7.98 & 3,598 & $>0.05$ \\
\hline & & & & Consumed leaves per plant & 6.34 & 3,598 & $>0.05$ \\
\hline PVY infected plants per plot & 17.27 & 3,58 & $<0.05$ & PVY infected plants per plot & 8.89 & 3,58 & $<0.05$ \\
\hline PVS infected plants per plot & 3.76 & 3,58 & $>0.05$ & PVS infected plants per plot & 7.46 & 3,58 & $>0.05$ \\
\hline PVM infected plants per plot & 7.84 & 3,58 & $>0.05$ & PVM infected plants per plot & 8.03 & 3,58 & $>0.05$ \\
\hline PVY + PVM infected plants per plot & 9.34 & 3,58 & $<0.05$ & PVY + PVM infected plants per plot & 8.87 & 3,58 & $<0.05$ \\
\hline PVY + PVS infected plants per plot & 9.43 & 3,58 & $<0.05$ & PVY + PVS infected plants per plot & 9.05 & 3,58 & $<0.05$ \\
\hline \multirow{6}{*}{ PVM + PVS infected plants per plot } & 8.12 & 3,58 & $>0.05$ & PVM + PVS infected plants per plot & 6.84 & 3,58 & $>0.05$ \\
\hline & & & & Viral symptoms per plant & 11.34 & 3,58 & $<0.05$ \\
\hline & & & & Total weight & 7.99 & 3,58 & $>0.05$ \\
\hline & & & & Weight of tubers in fraction $=80 \mathrm{~g}$ & 5.78 & 3,58 & $>0.05$ \\
\hline & & & & Weight of tubers in fraction $=50 \mathrm{~g}$ & 3.76 & 3,58 & $>0.05$ \\
\hline & & & & Weight of tubers in fraction $<50 \mathrm{~g}$ & 3.76 & 3,58 & $>0.05$ \\
\hline \multicolumn{8}{|l|}{ Endophytic rate } \\
\hline RNase activity in plants & 5.34 & 4,597 & $>0.05$ & RNase activity in plants & 4.67 & 4,597 & $>0.05$ \\
\hline Eggs & 6.88 & 4,597 & $<0.05$ & & & & \\
\hline \multirow[t]{2}{*}{ Young instar larvae } & 10.97 & 4,597 & $<0.05$ & Last instar larvae & 6.97 & 4,597 & $<0.05$ \\
\hline & & & & Consumed leaves per plant & 6.86 & 4,597 & $<0.05$ \\
\hline PVY infected plants per plot & 3.78 & 4,57 & $>0.05$ & PVY infected plants per plot & 5.03 & 4,57 & $>0.05$ \\
\hline PVS infected plants per plot & 5.87 & 4,57 & $<0.05$ & PVS infected plants per plot & 7.56 & 4,57 & $<0.05$ \\
\hline PVM infected plants per plot & 7.12 & 4,57 & $<0.05$ & PVM infected plants per plot & 6.17 & 4,57 & $<0.05$ \\
\hline PVY + PVM infected plants per plot & 3.02 & 4,57 & $>0.05$ & PVY + PVM infected plants per plot & 4.57 & 4,57 & $>0.05$ \\
\hline PVY + PVS infected plants per plot & 4.55 & 4,57 & $>0.05$ & PVY + PVS infected plants per plot & 1.77 & 4,57 & $>0.05$ \\
\hline \multirow[t]{6}{*}{ PVM + PVS infected plants per plot } & 5.14 & 4,57 & $>0.05$ & PVM + PVS infected plants per plot & 3.01 & 4,57 & $>0.05$ \\
\hline & & & & Viral symptoms per plant & 5.94 & 4,597 & $<0.05$ \\
\hline & & & & Total weight & 5.78 & 4,57 & $<0.05$ \\
\hline & & & & Weight of tubers in fraction $=80 \mathrm{~g}$ & 8.37 & 4,57 & $<0.05$ \\
\hline & & & & Weight of tubers in fraction $=50 \mathrm{~g}$ & 3.87 & 4,57 & $>0.05$ \\
\hline & & & & Weight of tubers in fraction $<50 \mathrm{~g}$ & 5.01 & 4,57 & $>0.05$ \\
\hline
\end{tabular}

Bacteria B. subtilis 26D was found in potato plant tissues in the amount of $350 * 10^{3} \mathrm{CFU} / \mathrm{g}$ of wet weight. The CFU numbers of Bacillus sp. TS2, B. subtilis 11VM, and B. thuringiensis B-5351 were broadly similar (70-120* $10^{3} \mathrm{CFU} / \mathrm{g}$ of wet weight). The ability of B. thuringiensis B-5689 and Bacillus sp. STL7 was an order of magnitude less than that of other strain showed, and the 
amount of Enterobacter sp. BC-8 was very low, and this strain was used as a negative control in the field experiments.

Thus, it was shown that the strains B. subtilis 26D and Bacillus sp. TS2 had a greater ability to actively invade and colonize plant tissues as compared with other strains and relatively high RNase activity and when then grown on LP medium cultures were used for inoculation. The influence of RNase activity on endophytic properties of strains was not significant (Table 4).

\section{Colorado Potato Beetle Population}

The average number of $\mathrm{CPB}$ eggs per plant ranged from $14.0 \pm 4.5$ and $15.4 \pm 3.9$ on water-treated and Enterobacter sp. BC-8 plants, respectively, to $4.6 \pm 2.2$ on $B$. thuringiensis B-5351treated plants (Figure 1I). A relatively low rate of egg clusters was observed on plants under the influence of Bacillus sp. STL7 and TS2, B. subtilis 11VM and 26D, and B. thuringiensis B-6066. Their effectiveness was similar to that of commercial biocontrol agent BTB (Figure 1I).

The average seasonal number of CPB early instar larvae per plant without endophytes was $15.8 \pm 1.23$ (Figure 1II). There were no statistically significant differences among water, Enterobacter sp. BC-8, and B. thuringiensis B-5689 treatments $(P>0.05)$. A significantly lower number of early instar larvae was found on plots treated with $B$. thuringiensis B-6066 and $B$. thuringiensis B-5351, B. subtilis strains under investigation, and B. sp. STL7 and Bacillus sp. TS2.

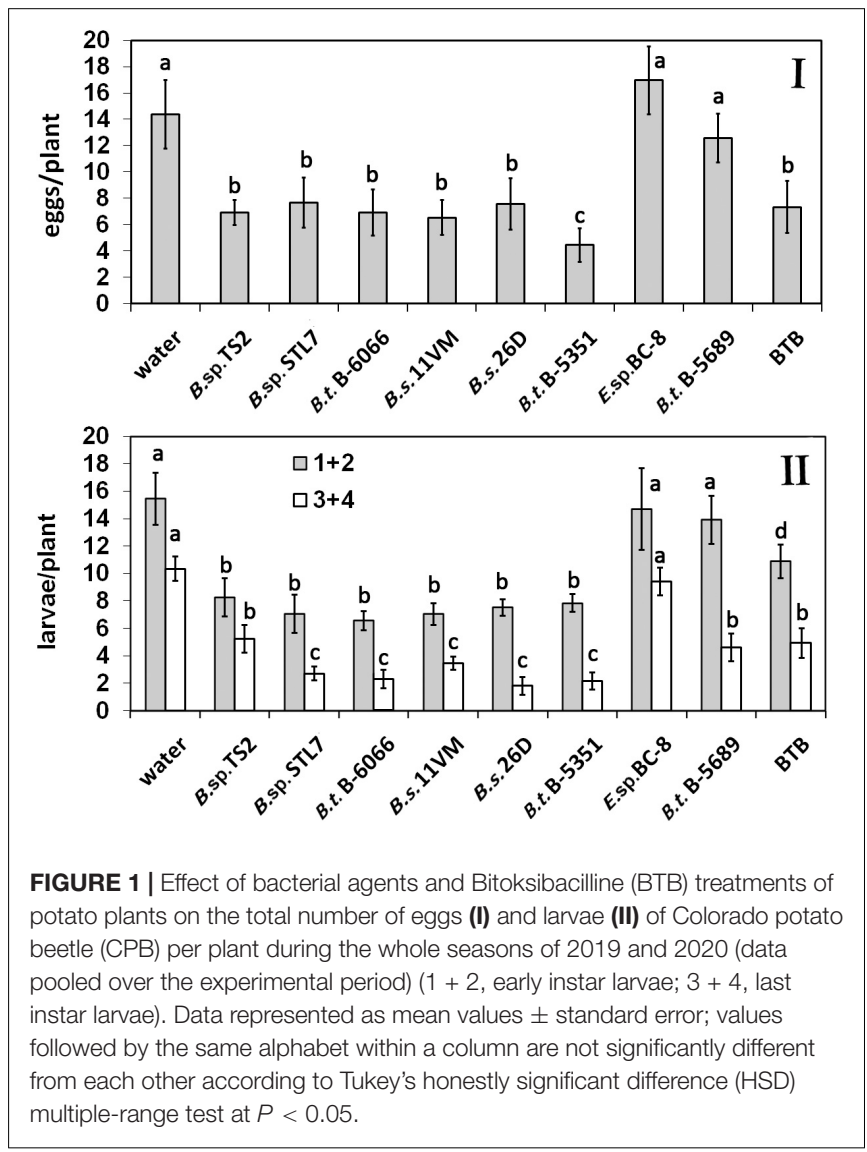

The number of last instar larvae on water-treated plants was $10.9 \pm 0.64$ per plant. Bacillus sp. STL7, B. subtilis 11VM, B. subtilis 26D, B. thuringiensis B-5689, B. thuringiensis B-6066, and BTB treatment gave a low number of last instar larvae (one third of control number). The amount of last instar larvae did not differ significantly from each other in plants that were under the influence of Bacillus sp. TS2, B. thuringiensis B-5689, and BTB accounted for half of this parameter on water-treated ones. On Enterobacter sp. BC-8 cell-treated plots, a higher number of last instar larvae per plant as compared with Bacillus spp.-treated plots were observed.

\section{Potato Virus Incidence}

Under the field conditions, a significant reduction of PVS incidence was recorded in plants treated with Bacillus sp. TS2, B. subtilis 26D, B. thuringiensis B-6066 ( $P<0.01$ in all cases) on the 17th day after the first treatment. The effect of another Bacillus spp. strains and isolate on PVS prevalence decrease was less severe but significant $(P<0.005)$ as compared with the water, $B$. thuringiensis B-5351, or Enterobacter sp. BC-8 treatments (Figure 2I). PVM was found in about $70 \%$ of potato plants, treated with water, B. thuringiensis B-5689, Enterobacter sp. BC8 , and BTB. The lowest percentage of PVM-infected plants was observed on Bacillus sp. TS2-treated plots (8.3\%). B. subtilis $26 \mathrm{D}$ and $B$. thuringiensis B-6066 decreased the incidence of PVM-positive plants by about $45 \%$ as compared with the water

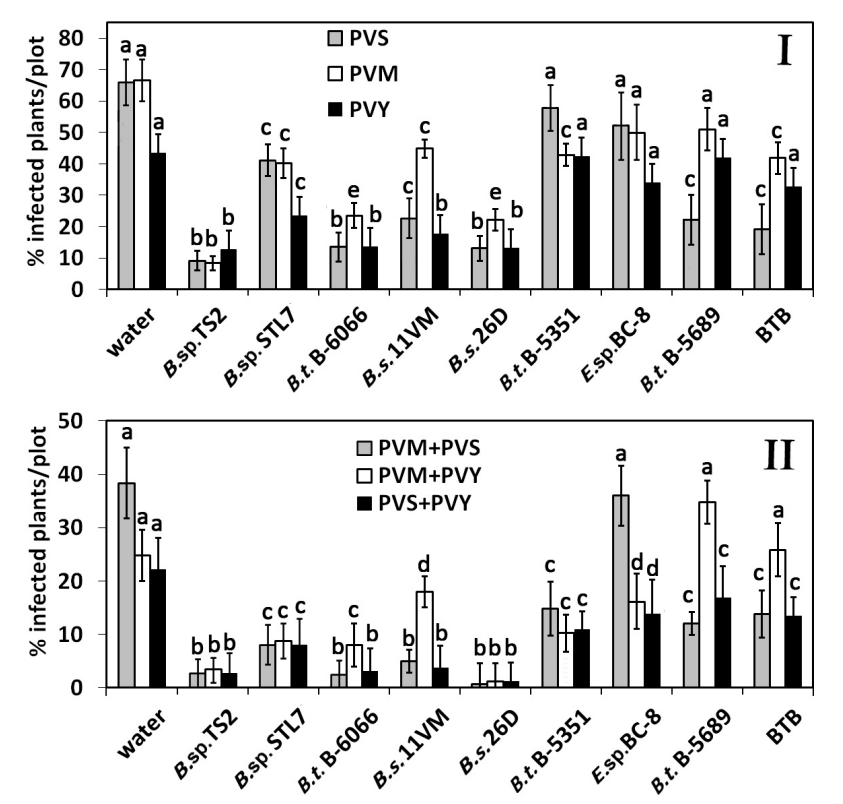

FIGURE 2 | Effect of bacterial agents and Bitoksibacilline (BTB) treatments of potato plants on the prevalence of potato virus $Y(P V Y)$, potato virus M (PVM), and potato virus S (PVS) on potato plots on the 17th day after treatment: percentage of samples that tested positively for each virus (I) and samples that tested positive for two viruses simultaneously (II). Data represented as mean values \pm standard error; values followed by the same alphabet within a column are not significantly different from each other according to Tukey's honestly significant difference (HSD) multiple-range test at $P<0.05$. 
treatment. B. sp. STL7, B. subtilis 11VM, and B. thuringiensis B5351 treatments were less effective, but decrease of viral incidence was significant in comparison with that of water-treated plots $(P<0.05$ in all cases $)$ and was as much as $15 \%$. Decrease of PVY prevalence was observed on plots that were sprayed with Bacillus sp. TS2, Bacillus sp. STL7, B. subtilis 11VM, B. subtilis 26D, and $B$. thuringiensis $\mathrm{B}-6066$ ( $P<0.01$ in all cases). It is important that Bacillus sp. TS2, B. subtilis 26D, and B. thuringiensis B-6066 contributed to decrease of prevalence rate of all viruses under investigation, and the incidence of plants that tested positive for two viruses simultaneously in these cases was less than $10 \%$; then in water-treated plots, this rate was more than 35\% (PVM + PVS) and more than 25\% (PVM + PVY and PVS + PVY) (Figure 2II).

A relatively low rate of mixed infections was observed in plots treated with $B$. sp. STL7 (about 10\%), B. subtilis 11VM (about $5 \%$ of plants infected with PVS + PVM and PVS + PVY), and B. thuringiensis B-5351 (about $15 \%$ of plants tested positive on two viruses simultaneously).

On the 31st (2019) and 29th (2020) days after first treatment, percentage of infected plants was not increased in plots treated with water, B. thuringiensis B-5351, B. thuringiensis B-5689, Enterobacter sp. BC-8, BTB, and B. sp. STL7 (Figure 3I). In Bacillus sp. TS2- and B. subtilis 26D-treated plots, the number of virus-infected plants increased by $10-15 \%$ compared with the previous measure. The number of PVM and PVY infected plants on B. subtilis 11VM-treated plots became the same as that of

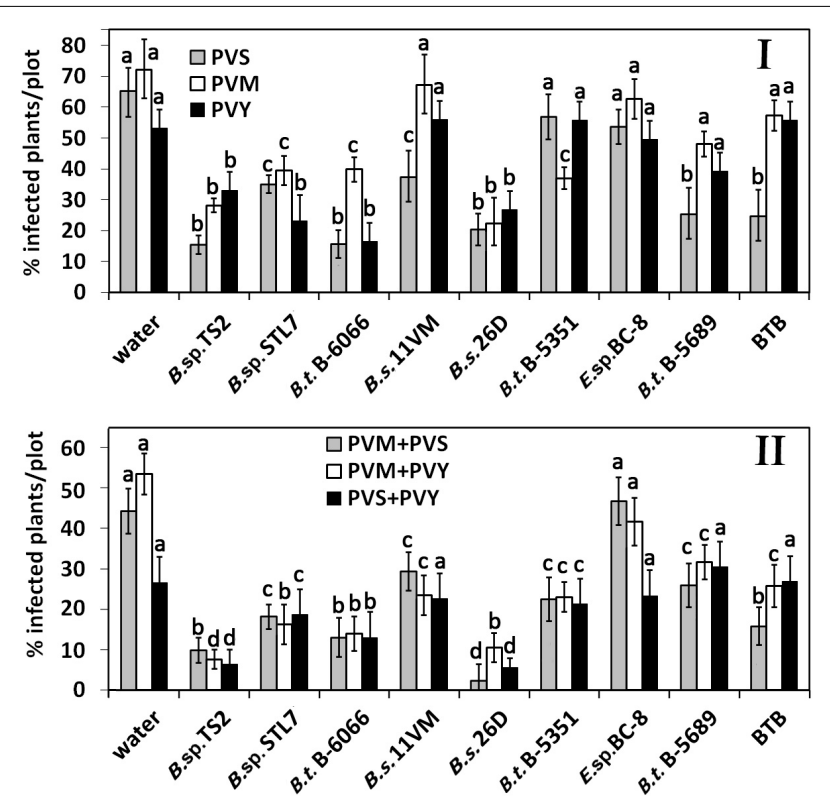

FIGURE 3 | Effect of bacterial agents and Bitoksibacilline (BTB) treatments of potato plants on the prevalence of potato virus $Y(P V Y)$, potato virus M (PVM), and potato virus S (PVS) in potato plots on the 31st day (2019) and 29th day (2020) after treatment: percentage of samples that tested positively for each virus (I) and samples that tested positive for two viruses simultaneously (II). Data represented as mean values \pm standard error; values followed by the same alphabet within a column are not significantly different from each other according to Tukey's honestly significant difference (HSD) multiple-range test at $P<0.05$. control plots. On BTB-treated plots, the number of PVM-infected plants had risen to those of control ones.

The rise of the number of plants tested positively on more than a single virus was observed on the 31st day after treatment (Figure 3II). A relatively low rate of mixed infections was observed in plots treated with B. thuringiensis B-6066, B. subtilis $26 \mathrm{D}$, and Bacillus sp. TS2 (about $8-12 \%$ of plants in all cases); Bacillus sp. STL7 (about 15\% of plants); and B. subtilis 11VM (increase of number of PVM + PVS- and PVS + PVY-infected plants). Importantly, the treatment with B. subtilis 26D led to the least number of plants positive as tested on PVS mixed infections.

Thus, treatments of plants with bacterial strains B. subtilis $11 \mathrm{VM}$, Enterobacter sp. BC-8, B. thuringiensis B-5689, and bioinsecticide BTB were least efficient against the most damaging viral disease that caused PVY and mixed infection of PVY (Figure 3II).

\section{Ribonuclease Activity in Bacillus-Treated Plants Under the Field Conditions}

The RNase activity rate in water-sprayed potato plants was about 3.5-4 units/mg of protein (Figure 4). Treatment of plants with Bacillus sp. TS2, B. subtilis 26D, and B. thuringiensis B6066 caused significant increase of RNase activity on both the 17th and 31st (2019) and 29th (2020) days after first treatment $(P<0.005)$. Bacillus sp. STL7 and B. thuringiensis B-5351 promoted RNase activity on the 17th day after first treatment almost equally, but this parameter became equal to the control ones subsequently. RNase activity in plants treated with other strains under investigation was equal to that estimated in watertreated ones.

\section{Defoliation and Viral Disease Symptoms}

Defoliation caused by Leptinotarsa decemlineata was minimal on plots treated with Bacillus sp. TS2, B. thuringiensis B-5351, and $B$. subtilis 26D. In these cases, it was almost one third of this parameter in water-treated plants $(P<0.01)$ (Figure 5I). Significant reduction of the defoliation level was observed on plants, treated with $B$. thuringiensis B-6066, Bacillus sp. STL7, and $B$. subtilis 11VM $(P<0.05)$. The influence of Enterobacter sp.

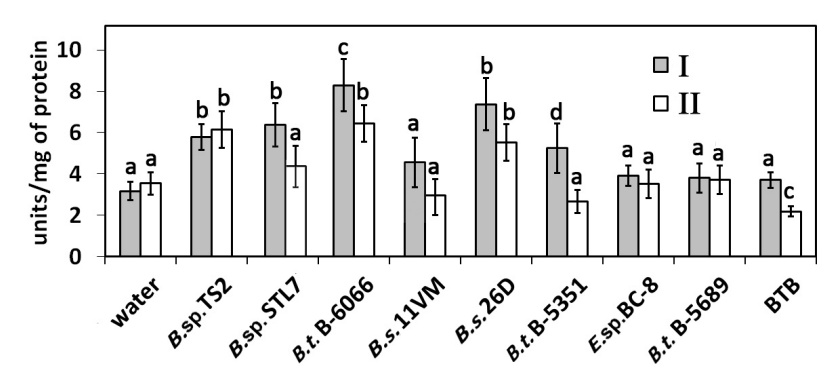

FIGURE 4 | RNase activity in potato plants treated with bacterial strains and Bitoksibacilline (BTB) on the 17th day (I) and the 31st day after treatment (II). Data represented as mean values \pm standard error; values followed by the same alphabet within a column are not significantly different from each other according to Tukey's honestly significant difference (HSD) multiple-range test at $P<0.05$. 


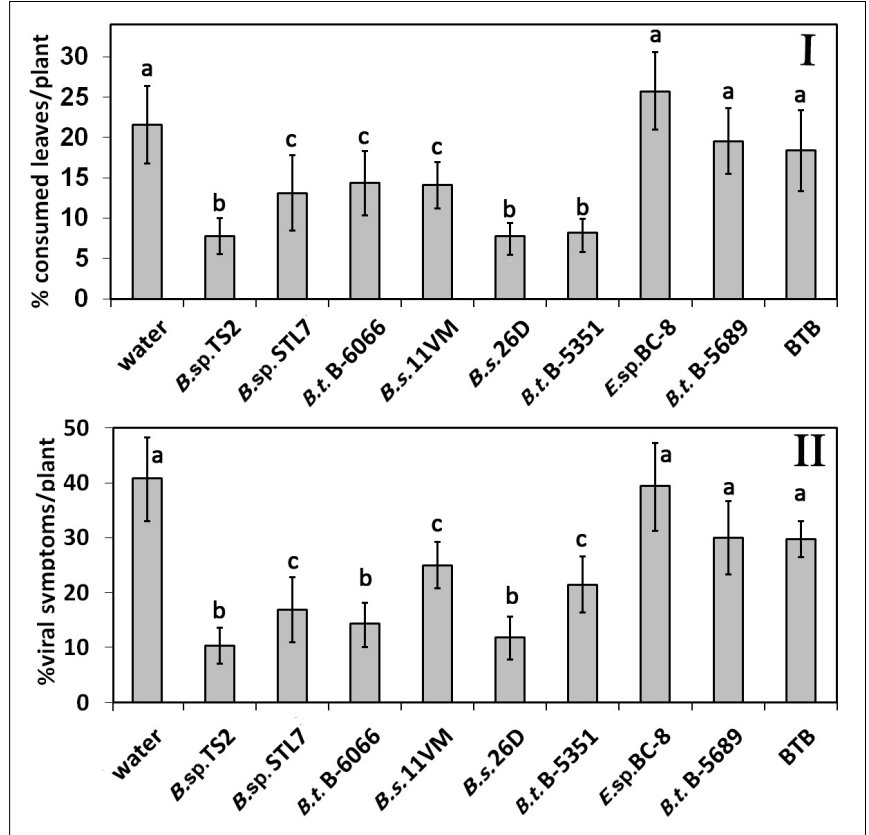

FIGURE 5 | Defoliation of potato plants caused by Leptinotarsa decemlineata (I) and percentage of viral diseases damaged leaves (II) of potato plants treated with bacterial agents and Bitoksibacilline (BTB). Data represented as mean values \pm standard error; values followed by the same alphabet within a column are not significantly different from each other according to Tukey's honestly significant difference (HSD) multiple-range test at $P<0.05$.

BC-8, B. thuringiensis B-5689, and biocontrol agent BTB did not show any significant influence on defoliation.

Viral disease symptoms including leaf deformation (crinkling) and size reduction with shiny appearance and yellow mottling that were caused by PVY or complex of PVY and PVM and/or PVS or chlorosis and mottling (complex of PVM and PVS) were estimated visually. Leaves with viral diseases signs constituted about a quarter of the leaves of entire plants treated with water, Enterobacter sp. BC-8, B. thuringiensis B-5351, and BTB. Disease severity significantly $(P<0.05)$ decreased under the influence of $B$. thuringiensis B-6066, B. sp. STL7, and B. subtilis 11VM (Figure 5II). In plants treated with Bacillus sp. TS2, B. subtilis $26 \mathrm{D}$, and $B$. thuringiensis B-5689, the lowest rate of leaves with disease symptoms was achieved $(P<0.01)$.

\section{Potato Yield Structure}

Among treatments with water, Enterobacter sp. BC-8, B. subtilis $11 \mathrm{VM}$, and $B$. thuringiensis B-5689, we did not establish significant differences in productivity (Figure 6). Slight increase of the yield was observed under the influence of Bacillus sp. STL7 and BTB. Bacillus sp. TS2, B. thuringiensis B-6066, $B$. thuringiensis $\mathrm{B}-5351$, and $B$. subtilis $26 \mathrm{D}$ treatments promoted the highest total yield.

The number of tubers in the fraction $>80 \mathrm{~g}$ was increased under the influence of all Bacillus spp. strains except Bacillus sp. STL7 and B. thuringiensis B-5689; in the fraction of 50-80 g, an increased amount was observed under the influence of all Bacillus treatments (Figure 7I). A decrease in the number of

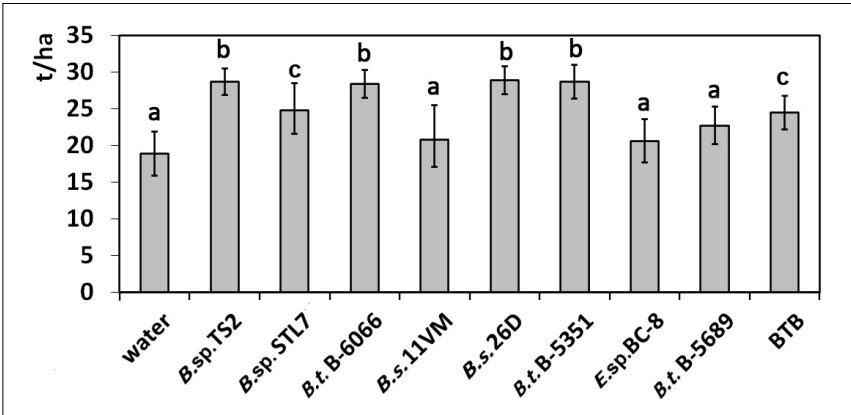

FIGURE 6 | Effect of bacterial agents and Bitoksibacilline (BTB) treatments of potato plants on the total potato yield. Data represented as mean values \pm standard error; values followed by the same alphabet within a column are not significantly different from each other according to Tukey's honestly significant difference (HSD) multiple-range test at $P<0.05$.

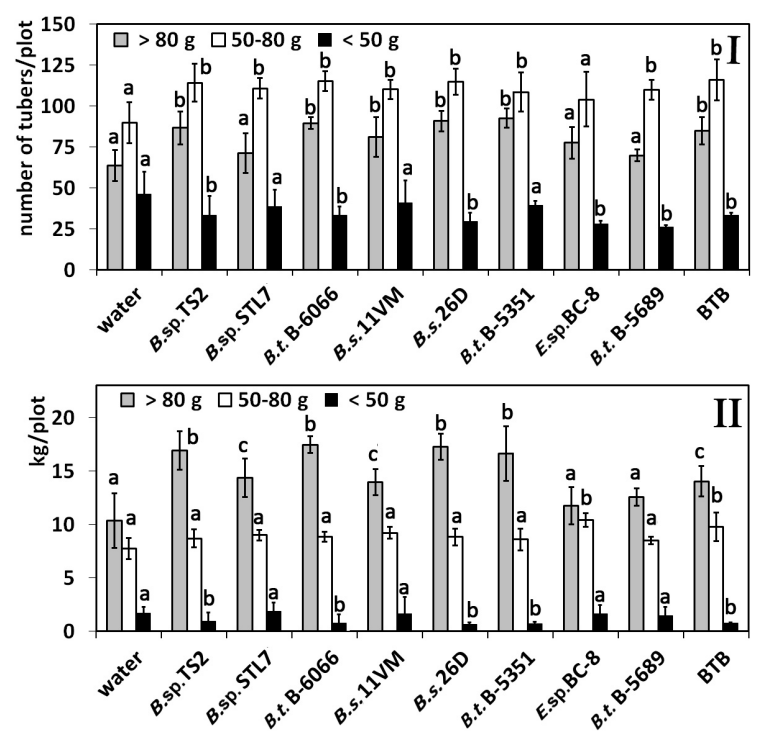

FIGURE 7 | Effect of bacterial agents and Bitoksibacilline (BTB) treatments of potato plants at different fractions. (I) Number of tubers in fraction; (II) weight of tubers in fractions. Data represented as mean values \pm standard error; values followed by the same alphabet within a column are not significantly different from each other according to Tukey's honestly significant difference (HSD) multiple-range test at $P<0.05$.

tubers in the fraction $<50 \mathrm{~g}$ under the influence of Bacillus $\mathrm{sp}$. TS2, B. thuringiensis B-6066, B. thuringiensis B-5689, B. subtilis 26D, and Enterobacter sp. BC-8 was observed.

Treatments with Bacillus sp. TS2, B. thuringiensis B-6066, B. thuringiensis B-5153, and B. subtilis $26 \mathrm{D}$ had the major weight of large $(>80 \mathrm{~g})$ tubers, while the least total weight of this fraction had tubers from plots that were treated with water, Enterobacter sp. BC-8, and B. thuringiensis B-5689 (Figure 7II). Bacillus sp. STL7, B. subtilis 11VM, and BTB promoted the increase of average weight of tubers in this fraction to a lesser degree than other strains under investigation and in accordance with the increase of total yield in these cases. Weight of tubers in the middle fraction was higher than that registered in water-treated 
plants only in cases of treatments with Enterobacter sp. BC-8 and BTB. Treatment of potato plants with cells of Bacillus sp. STL7 and B. thuringiensis B-5689 and Enterobacter sp. BC-8 were not influenced on weight of tubers in the fraction $<50 \mathrm{~g}$ in contrast to other strains that decrease this parameter.

\section{DISCUSSION}

Modern agriculture is the foundation stone for food security and one of the major dangers compromising the environment on a global scale. Plants, most especially agricultural species, are constantly falling under diverse biotic impacts, which damage plant organisms and decrease production value and quality. On the one hand, at the moment, the greatest task is improving or maintaining the food quality. On the other hand, it is important to keep damage caused to the environment to a minimum. Viruses cause epiphytotics in all species of cultivated plants, but the control of viral vectors is still a solitary measure to decrease their presence. Thus, there are no currently effective chemical means of plant protection against viruses. Unfortunately, there are not much dominant resistance genes against viruses in cultivated plants. Genome-editing technologies are more efficient to control viral diseases but raise concerns for their safety.

Numerous researches on beneficial microorganisms exist, but there is little information on the ability of biological agents to control the spread of different harmful pathogens and pests which simultaneously influence agricultural plants. And furthermore, some research of the influence of PGPB on the spread of viruses focuses on their impact on insect vectors, such as aphids and whiteflies. Viral infections of plants, however, had a significant effect on behavior of the CPBs. Booth and Alyokhin (2016) showed that CPB larvae and adults predominantly colonized virus-free plants in comparison with PVY-infected plants, since infected plants had poorer growth and reduced ability to sprout novel foliage after CPB damage. The latest can determine strong selection pressure for choosing PVY-free plants. PVY infection decreased plant resistance to non-vector herbivores, Leptinotarsa decemlineata, and Trichoplusia ni in increasing their growth rates (Kersch-Becker and Thaler, 2014). The development of efficient and durable resistance of plants able to withstand viral attacks represents a major challenge for agrobiology. Currently, the spread of viruses cannot be controlled with chemical pesticides, and microbes that are beneficial to plants can be an alternative due to their ability to synthesize antiviral compounds directly in plant tissues or induce plant defense reactions.

The capability of PGPB to moderate virus spread and reproduction in plants was reported in a great number of studies (Maksimov et al., 2020). Unfortunately, there are only few studies available on the status of these bacterial strains within host plants and their ability to interact with the host and to exist endophytically. Observed under laboratory or greenhouse conditions, the potential of PGPB to improve crop production and increase yields became unexpected and incalculable under different field conditions (Bly et al., 2009). The sensitivity of PGPB strains to the plant defense mechanisms and soil conditions as well as usual flushing with rain limits their ability to colonize the rhizosphere and plant tissues or surfaces and express beneficial influence on host plants (Cakmakçi et al., 2006). The promising approach of agricultural plant protection against viruses involves investigating the composition and role of plant microbiome in order to develop environmentally safe biocontrol agents with diverse beneficial properties (growthpromoting activity, priming of plant immune reactions against pathogens and pests, and direct pesticidal effects) for plant protection against viral diseases and vector and non-vector pests.

In this study, we investigate Bacillus spp. strains capable of penetrating internal plant tissues in different degrees. The Bacillus subtilis 26D showed the maximal number of CFU in potato plant tissues; Bacillus thuringiensis B-5689 showed the minimal number among endophytic strains. Enterobacter sp. BC-8 had no endophytic properties. This strain was found in CPB intestines (Sorokan et al., 2019), and its presence in internal plant tissues can partly be explained by CPB attacks. The endophytic rate of bacteria significantly influenced insect population (number of eggs and young larvae per plant) of consumed leaves per plant, PVS and PVM incidence on early and latest stage and viral symptoms on leaves per plant, and plant productivity (weight of tubers in the fraction $\geq 80 \mathrm{~g}$ ) (see Supplementary Material).

It was found that according to the results of the 2-year experiments between "endophytic level" of the strain, used for treatment and productivity of plants $(r=0.745256)$, weight of tubers in the fraction $\geq 80 \mathrm{~g}(r=0.764837)$, number of young larvae per plant $(r=-0.643567)$, and PVS incidence $(r=-0.865972)$, strong correlations were observed. Thus, the number of cells of endophytic microorganisms in plant tissues itself was not a decisive factor in plant protection against viruses, but, probably, this property allowed PGPB to synthesize their metabolites, in particular RNases and Bt-toxines, inside plant organisms.

A lot of Bacillus species produce extracellular high-molecularweight RNases (Maksimov et al., 2019). It was established that treatment of tobacco plants with $100 \mu \mathrm{g} / \mathrm{mg}$ of RNase from Bacillus pumilus directly suppressed the development of PVS and PVM infection and almost completely inhibited PVX infection, as well as decreased the red clover mottle virus (RCMV) particle number in pea plants (Fedorova et al., 2011). B. pumilus 7P/319 extracellular RNases decreased the spread of RNA viruses RCMV, PVX, and alfalfa mosaic virus in pea plants. The maximum inhibitory effect against viruses under investigation was observed when plants were treated with $100 \mu \mathrm{g} / \mathrm{ml}$ of RNase prior to infection (Sharipova et al., 2015). In this regard, an alternative strategy for protecting plants from viruses can be based on the use of microbial enzymes, for example, extracellular nucleases or proteases of Bacillus spp. In our investigation, the strong impact of RNase activity of bacterial agents used for the treatment on PVY incidence (early stage $r=-0.76322$, latest stage $r=-0.5734$ ), mixed infections PVM + PVY (early stage $r=-0.8675$ ), and PVY + PVS (early stage $r=-0.6543$ ) incidence was observed (Table 4).

It is worth noting that the effect of RNase activity of bacteria on total RNase activity in potato plants under the field conditions was significant for early stage of viral spreading, 
and the level of RNase activity of bacterial strain in vitro corresponded to the total level of RNase activity in potato plants (system plant + endophyte). Later, a high level of RNase activity was observed only in plants treated with agents, which demonstrates high RNase activity and pronounced ability to establish endophytic relations with host plant simultaneously (Bacillus sp. TS2, B. thuringiensis B-6066, and B. subtilis 26D). This fact probably increased plant resistance to viruses. Thus, for buckwheat varieties Roksolana and Kara-Dag with different resistance to the buckwheat burn virus (BBV), a positive correlation between resistance to virus and RNase activity was shown (Sindarovska et al., 2014). Trifonova et al. (2018) have proposed to use the level of RNase activity in potato leaves as a selective marker for resistance to viruses.

Since endophytic strains producing RNases inhibited the spread of viruses and affected viral symptom expression, bacterial strains combining a high endophytic rate and high RNase activity, such as Bacillus sp. TS2 and B. subtilis 26D, can be used for biocontrol agents development. Hameed et al. (2014) concluded that multiple viral infections (for example, widespread PVS + PVY and PVM + PVY joint infections) cause dramatic escalation of plant damage as compared with a single infection. Under the influence of Bacillus sp. TS2, and B. subtilis 26D abundance of plants positively tested on more than one virus tend toward zero, and these bacterial agents should be considered as effective means for plant protection against viral diseases.

In our investigation, percentage of defoliation caused by $\mathrm{CPB}$ correlated with disease symptoms severity $(r=0.6771)$. It was found previously that pea enation mosaic virus (PEMV)-infected pea plants experienced more defoliation from non-vector pea leaf weevil, Sitona lineatus, than uninfected plants. In turn, vector of PEMV, pea aphid Acyrthosiphon pisum, prevalently affected plants that were previously being damaged by S. lineatus. Weevil herbivory forced PEMV titer in infected plants (Chisholm et al., 2018). Su et al. (2020) found that non-vector Tetranychus urticae infestation promoted vector Bemisia tabaci feeding of Solanum lycopersicum plants, thereby increasing tomato yellow leaf curl virus (TYLCV) transmission to tomato plants.

Bacillus sp. TS2, B. thuringiensis B-5351, and B. subtilis $26 \mathrm{D}$ significantly decreased defoliation caused by CPB; i.e., they showed antifeedant effect on CPB when they were used for potato plants treatment as well as attractiveness of plants for oviposition. It is particularly significant that $B$. thuringiensis $\mathrm{B}-5689$ provided for a one-third increase in the mortality of $L$. decemlineata larvae as if under the influence of B. subtilis 26D under the laboratory conditions (Sorokan et al., 2018) but had no significant impact on pest population density in the field, probably due to its low ability to invade internal plant tissues. We found that endophytic strains that showed insecticidal activity-B. thuringiensis B-5351 and B. thuringiensis B-6066 (Sorokan et al., 2019), synthesizing Cryprotein, and B. subtilis 26D disturbing CPB microbiota (Sorokan et al., 2016)—effectively decreased abundance of $L$. decemlineata eggs, and young and old larvae and the defoliation level. Thus, there were steady and substantial limited amounts of plants infected with viruses and disease severity on plots treated with bacteria, which combine pronounced entophytic properties, RNase activity, and previously established insecticidal activity.
The population density of CPB in Laznik et al. (2010) field experience increased since the beginning of the vegetation season, and in the middle of cultivation period, damage caused by $\mathrm{CPB}$ was the most serious. Weight and amount of small tubers harvested from plants that were less damaged (thiamethoxam treatment) were smaller, while the mass of large tubers was higher than from severely damaged plants. Thus, defoliation of potato plants influenced the tuber developments in such a way that potato plants produced smaller tubers that were unable to grow in size. In our investigation, treatment with Bacillus sp. TS2, B. subtilis 26D, B. thuringiensis B-6066, and B. thuringiensis $B-5351$ increased the total yield and weight of large tubers ( $\geq 80 \mathrm{~g}$ ) harvested per plot. The number of tubers in this class was equally increased compared with that of control ones in all cases except Enterobacter sp. BC-8 and B. thuringiensis B-5689. The increase of total yield, in particular, weight of tubers in the fraction $\geq 80 \mathrm{~g}$, was correlated depending on the range of bacteria in the internal tissues $(r=0.77353)$.

Amount and the mass of medium (50-80 g) tubers were the same in plots under the influence of all Bacillus under investigation. In the cases of plants treated with B. subtilis $26 \mathrm{D}$, B. sp. TS2, B. thuringiensis B-5351, and B. thuringiensis B-6066, which increased the weight of large tubers, the formation of small tubers was lower than of control plots. Similar results were reported by Bakhvalova et al. (2015), who showed that the biomass of potato tubers was increased under the influence of $B$. thuringiensis $\mathrm{H} 10$ strain due to the enhancement of quantity and weight of tubers in $\geq 80$-g class, and distribution of Rhizoctonia on potato stolons decreased almost twice. Soil drenching with B. subtilis KU936344, KU936345, and KU936341 strains led to the higher yield of market-grade potato tubers and less unfit for trading tubers, even when compared with plots treated with fungicide Mancozeb (Kumbar et al., 2019). It is important that, in our experiments, high yield was obtained under the influence of strains that combine endophytic properties, RNase activity, and antifeedant effect on the pest.

\section{CONCLUSION}

Thus, the reinforcement of agroecosystems with endophytic microorganisms that can produce RNases directly in plant tissues is a promising strategy for the advancement of virus management. Results of our research showed that endophytic Bacillus sp. TS2, B. subtilis 26D, and B. thuringiensis B-5351 were effective biological agents in the control of CPB and viral diseases of potato. These strains can be used for the development of multifunctional biocontrol agents (insecticide + viricide), which can be more effective than modern mono-active chemical pesticides.

\section{DATA AVAILABILITY STATEMENT}

The datasets presented in this article are not readily available because: there is not any restrictions. Requests to access the datasets should be directed to fourtyanns@googlemail.com. 


\section{AUTHOR CONTRIBUTIONS}

AS designed and conducted the study, harvested the samples, collected the data, and wrote the manuscript. EC, GBu, SV, and ES conducted the study and collected the data. SR, VA, GBe, and IM harvested the samples and conducted field experiments. RK polished the manuscript. IM proposed the research and managed the funding. All authors contributed to the article and approved the submitted version.

\section{FUNDING}

This study was supported by joint international grant of the Russian Science Foundation No. 19-46-02004 and the Department of Science and Technology (DST),

\section{REFERENCES}

Alyokhin, A., Baker, M., Mota-Sanchez, D., Dively, G., and Grafius, E. (2008). Colorado potato beetle resistance to insecticides. Am. J. Potato Res. 85, 395-413. doi: 10.1007/s12230-008-9052-0

Aman, R., Ali, Z., Butt, H., Mahas, A., Aljedaani, F., Khan, M. Z., et al. (2018). RNA virus interference via CRISPR/Cas13a system in plants. Genome Biol. 19, 77-89. doi: 10.1186/s13059-017-1381-1

Aydi Ben Abdallah, R., Jabnoun-Khlareddine, H., Nefzi, A., Mokni-Tlili, S., and Daami-Remadi, M. (2016). Biocontrol of Fusarium wilt and growth promotion of tomato plants using endophytic bacteria isolated from Solanum elaeagnifolium stems. J. Phytopathol. 164, 811-824. doi: 10.1111/jph. 12501

Bakhvalova, S. A., Tsvetkova, V. P., Shpatova, T. V., Shternshis, M. V., and Grishechkina, S. D. (2015). Ecological interactions in the system: entomopathogenic bacterium Bacillus thuringiensis-phytopathogenic fungus Rhizoctonia solani-host plant Solanum tuberosum. Contemp. Problems Ecol. 8, 534-539. doi: 10.1134/S1995425515040034

Bly, U., Woodard, H., and Gelderman, R. (2009). Biological Inoculants and Other Products for Soybeans During 2009 (44309 and 44409). Brookings, SD: South Dakota State University.

Boiteau, G., and Singh, R. P. (1982). Effect of potato foliage infected with potato leafroll virus on fecundity and longevity of the Colorado potato beetle, Leptinotarsa decemlineata (Coleoptera: Chrysomelidae). Can. Entomol. 114, 473-477. doi: 10.4039/Ent114473-6

Booth, E., and Alyokhin, A. (2016) Colorado Potato beetle response to potato plants infected with potato virus $\mathrm{Y}$ and potato leafroll virus. Am. J. Potato Res. 93, 213-223. doi: 10.1007/s12230-016-9497-5

Bouizgarne, B. (2012). "Bacteria for plant growth promotion and disease management," in Bacteria in Agrobiology: Disease Management, Maheshwari, ed. K. Dhamu (Berlin: Springer), 15-46. doi: 10.1007/978-3-642-33639-3_2

Cakmakçi, R., Dönmez, F., Ayd $\iota n$, A., and Şahin, F. (2006). Growth promotion of plants by plant growth-promoting rhizobacteria under greenhouse and two different field soil conditions. Soil Biol. Biochem. 38, 1482-1487. doi: 10.1016/j. soilbio.2005.09.019

Chisholm, P. J., Sertsuvalkul, N., Casteel, C. L., and Crowder, D. W. (2018) Reciprocal plant-mediated interactions between a virus and a non-vector herbivore. Ecology 99, 2139-2144. doi: 10.1002/ecy.2449

De Fazio, G., Caner, J., and Vicente, M. (1980). Effect of Virazole (Ribavirin) on tomato spotted wilt virus in two systemic hosts, tomato and tobacco. Arch.Virol. 63, 305-309. doi: 10.1007/BF01315037

Domínguez-Arrizabalaga, M., Villanueva, M., Fernandez, A. B., and Caballero, P. (2019). A strain of Bacillus thuringiensis containing a novel cry7Aa2 gene that is toxic to Leptinotarsa decemlineata (Say) (Coleoptera: Chrysomelidae). Insects 10:E259. doi: 10.3390/insects10090259

Fedorova, A. A., Azzami, K., Ryabchikova, E. I., Spitsyna, Y. E., Silnikov, V. N., Ritter, W., et al. (2011). Inactivation of a non-enveloped RNA virus by artificial
International Division, Government of India No. C/1756/IFD/ 2019-20.

\section{ACKNOWLEDGMENTS}

Equipment of "Biomika" (Department of Biochemical Research Methods and Nanobiotechnology Center "Agidel") and USC "KODINK" was used.

\section{SUPPLEMENTARY MATERIAL}

The Supplementary Material for this article can be found online at: https://www.frontiersin.org/articles/10.3389/fmicb. 2020.569457/full\#supplementary-material

ribonucleases: honey bees and acute bee paralysis virus as a new experimental model for in vivo antiviral activity assessment. Antivir. Res. 91, 267-277. doi: 10.1016/j.antiviral.2011.06.011

Gray, S. M., and Power, A. G. (2018). Anthropogenic influences on emergence of vector-borne plant viruses: the persistent problem of Potato virus Y. Curr. Opin. Virol. 33, 177-183. doi: 10.1016/j.coviro.2018.10.002

Hameed, A., Iqbal, Z., Asad, S., and Mansoor, S. (2014). Detection of multiple potato viruses in the field suggests synergistic interactions among potato viruses in Pakistan. Plant Pathol. J. 30, 407-415. doi: 10.5423/PPJ.OA.05.20 14.0039

Hare, J. D., and Dodds, J. A. (1987). Survival of the Colorado potato beetle on virusinfected tomato in relation to plant nitrogen and alkaloid content. Entomol. Experiment. Appl. 44, 31-35. doi: 10.1111/j.1570-7458.1987.tb02236.x

Hussain, A., Arif, M., Abbas, A., Hussain, B., Ali, M., and Jaffar, S. (2016). A review on aphid-borne virus (Potato Virus Y). J. Entomol. Zool. Stud. 4, 189-192. doi: 10.13140/RG.2.1.1661.7844

Idris, A. L., Fan, X., Muhammad, M. H., Guo, Y., Guan, X., and Huang, T. (2020). Ecologically controlling insect and mite pests of tea plants with microbial pesticides: a review. Arch. Microbiol. 202, 1275-1284. doi: 10.1007/s00203-02001862-7

Ilinskaya, O., Ulyanova, V., Lisevich, I., Dudkina, E., Zakharchenko, N., Kusova, A., et al. (2018). The native monomer of Bacillus pumilus ribonuclease does not exist extra-cellularly. BioMed. Res. Int. 2018:ID4837623. doi: 10.1155/2018/ 4837623

Ilinskaya, O. N., Karamova, N. S., Ivanchenco, O. B., and Kipenskaya, L. V. (1996) SOS-inducing ability of native and mutant microbial ribonucleases. Mutation Res. 354, 203-209. doi: 10.1016/0027-5107(96)00012-7

Kersch-Becker, M. F., and Thaler, J. S. (2014). Virus strains differentially induce plant susceptibility to aphid vectors and chewing herbivores. Oecologia 174, 883-892. doi: 10.1007/s00442-013-2812-7

Khalaf, E. M., and Raizada, M. N. (2018). Bacterial seed endophytes of domesticated cucurbits antagonize fungal and oomycete pathogens including powdery mildew. Front. Microbiol. 9:42. doi: 10.3389/fmicb.2018. 00042

Kumbar, B., Mahmood, R., Nagesha, S. N., Nagaraja, M. S., Prashant, D. G., Zablon, O., et al. (2019). Field application of Bacillus subtilis isolates for controlling late blight disease of potato caused by Phytophthora infestans. Biocatal. Agricult. Biotechnol. 22:101366. doi: 10.1016/j.bcab.2019.101366

Laznik, Ž, Tóth, T., Lakatos, T., Vidrih, M., and Trdan, S. (2010). Control of the Colorado potato beetle (Leptinotarsa decemlineata [Say]) on potato under field conditions: a comparison of the efficacy of foliar application of two strains of Steinernema feltiae (Filipjev) and spraying with thiametoxam. J. Plant Dis. Protect. 117, 129-135. doi: 10.1007/BF03356348

Li, H., Soares, M. A., Torres, M. S., Bergen, M., and White, J. (2015). Endophytic bacterium, Bacillus amyloliquefaciens, enhances ornamental hosta resistance to diseases and insect pests. J. Plant Interact. 10, 224-229. doi: 10.1080/17429145. 2015.1056261 
Makarova, S. S., Makarov, V. V., Taliansky, M. E., and Kalinina, N. O. (2017). Virus resistance in potato: current state and prospects. Russ. J. Genet. Appl. Res. 7, 845-857. doi: 10.1134/S2079059717050148

Maksimov, I. V., Blagova, D. K., Veselova, S. V., Sorokan, A. V., Burkhanova, G. F., Cherepanova, E. A., et al. (2020). Recombinant Bacillus subtilis 26DCryChS line with gene BtcrylIa encoding Cry1Ia toxin from Bacillus thuringiensis promotes integrated wheat defense against pathogen Stagonospora nodorum Berk. and greenbug Schizaphis graminum Rond. Biol. Control. 144:104242. doi: 10.1016/j. biocontrol.2020.104242

Maksimov, I. V., Maksimova, T. I., Sarvarova, E. R., and Blagova, D. K. (2018). Endophytic bacteria as effective agents of new-generation biopesticides (A Review). Appl. Biochem. Microbiol. 54, 128-140. doi: 10.1134/S0003683818020072

Maksimov, I. V., Sorokan, A. V., Burkhanova, G. F., Veselova, S. V., Alekseev, V., Shein, M., et al. (2019). Mechanisms of plant tolerance to rna viruses induced by plant-growth-promoting microorganisms. Plants 8:575. doi: 10 . 3390/plants8120575

Mishra, J., Tewari, S., Singh, S., and Arora, N. K. (2015). "Biopesticides: where we stand?, in Plant-Microbes Symbiosis: Applied Facets, ed. N. K. Arora (Berlin: Springer), 37-75. doi: 10.1007/978-81-322-2068-8_2

Moreno, A. B., and López-Moya, J. J. (2020). When viruses play team sports: mixed infections in plants. Phytopathol. 110:1. doi: 10.1094/PHYTO-07-19-0250-FI

Pakniat-Jahromy, A., Behjatnia, S. A., Dry, I. B., Izadpanah, K., and Rezaian, M. A. (2010). A new strategy for generating geminivirus resistant plants using a DNA betasatellite/split baRNase construct. J. Virol. Methods 170, 57-66. doi: 10.1016/ j.jviromet.2010.08.019

Petek, M., Rotter, A., Kogovšek, P., Baebler, Š, Mithöfer, A., and Gruden, K. (2014). Potato virus $\mathrm{Y}$ infection hinders potato defense response and renders plants more vulnerable to Colorado potato beetle attack. Mol. Ecol. 23, 5378-5391. doi: $10.1111 / \mathrm{mec} .12932$

Pruss, G., Ge, X., Shi, X. M., Carrington, J. C., and Bowman, V. (1997). Plant viral synergism: the potyviral genome encodes a broad-range pathogenicity enhancer that transactivates replication of heterologous viruses. Plant Cell 9, 859-868. doi: $10.1105 /$ tpc.9.6.859

Rashid, M. H., and Chung, Y. R. (2017). Induction of systemic resistance against insect herbivores in plants by beneficial soil microbes. Front. Plant Sci. 8:1816. doi: $10.3389 /$ fpls.2017.01816

Sansinenea, E. (2019). “Bacillus spp.: as plant growth-promoting bacteria," in Secondary Metabolites of Plant Growth Promoting Rhizomicroorganisms, eds H. Singh, C. Keswani, M. Reddy, E. Sansinenea, and C. García-Estrada (Singapore: Springer).

Sharipova, M., Rockstroh, A., Balaban, N., Mardanova, A., Toymentseva, A., Tikhonova, A., et al. (2015). Antiviral Effect of Ribonuclease from Bacillus pumilus against phytopathogenic RNA-Viruses. Agric. Sci. 6, 1357-1366. doi: 10.4236/as.2015.611130

Sindarovska, Y. R., Guzyk, O. I., Yuzvenko, L. V., Demchenko, O. A., Didenko, L. F., Grynevych, O. I., et al. (2014). Ribonuclease activity of buckwheat plant (Fagopyrum esculentum) cultivars with different sensitivities to buckwheat burn virus. Ukr Biochem. J. 86, 33-40.

Sokurenko, Y., Nadyrova, A., Ulyanova, V., and Ilinskaya, O. (2016). Extracellular ribonuclease from Bacillus licheniformis (balifase), a new member of the N1/T1 RNase superfamily. BioMed. Res. Int. 2016:4239375. doi: 10.1155/2016/42 39375
Soosaar, J. L., Burch-Smith, T. M., and Dinesh-Kumar, S. P. (2005). Mechanisms of plant resistance to viruses. Nat. Rev. Microbiol. 3, 789-798. doi: 10.1038/ nrmicro1239

Sorokan, A. V., Benkovskaya, G. V., Blagova, D. K., Maksimova, T. I., and Maksimov, I. V. (2018). Defense responses and changes in symbiotic gut microflora in the colorado potato beetle Leptinotarsa decemlineata under the effect of endophytic bacteria from the genus Bacillus. J. Evol. Biochem. Physiol. 54, 300-307. doi: 10.1134/S0022093018040063

Sorokan, A. V., Ben'kovskaya, G. V., and Maksimov, I. V. (2016). The influence of potato endophytes on Leptinotarsa decemlineata endosymbionts promotes mortality of the pest. J. Invertebrate Pathol. 136, 65-67. doi: 10.1016/j.jip.2016. 03.006

Sorokan, A. V., Burkhanova, G. F., Benkovskaya, G. V., and Maksimov, I. V. (2019). Colorado potato beetle microsymbiont Enterobacter BC-8 inhibits defense mechanisms of potato plants using crosstalk between jasmonate- and salicylatemediated signaling pathways. Arthr. Plant Interact. 14, 161-168. doi: 10.1007/ s11829-019-09732-w

Su, Q., Yang, F., Yao, Q., Peng, Z., Shaoli, H. T., Xie, W. W., et al. (2020). A non-vector herbivore indirectly increases the transmission of a vector-borne virus by reducing plant chemical defenses. Funct. Ecol. 34, 1091-1101. doi: 10.1111/1365-2435.13535

Trifonova, E. A., Ibragimova, S. M., Volkova, O. A., Shumny, V. K., and Kochetov, A. V. (2018). Ribonuclease activity as a new prospective disease resistance marker in potato. Vavilov J. Genet. Breed. 22, 987-991. doi: 10.18699/VJ18.441

Ulyanova, V., Mahmud, R. Sh, Dudkina, E., Vershinina, V., Domann, E. and Ilinskaya, O. (2016). Phylogenetic distribution of extracellu-lar guanylpreferring ribonucleases renews taxonomic status of two Bacillus strains. J. Gen. Appl. Microbiol. 62, 181-188. doi: 10.2323/jgam.2016.02.005

Yang, J., Guo, C., Zhai, X., Shen, L., Qian, Y., and Wang, F. (2012). Inactivation of Tobacco mosaic virus in soil by Pseudomonas putida A3-m strain to prevent virus mosaic disease. Afr. J. Microbiol. Res. 6, 6300-6307. doi: 10.5897/AJMR12. 1123

Yang, S. Y., Lim, D. J., Noh, M. Y., Kim, J. C., Kim, Y. C., and Kim, I. S. (2017). Characterization of biosurfactants as insecticidal metabolites produced by Bacillus subtilis Y9. Entomol. Res. 47, 55-59. doi: 10.1111/1748-5967. 12200

Yang, X., Niu, L., Zhang, W., He, H., Yang, J., Xing, G., et al. (2019). Increased multiple virus resistance in transgenic soybean overexpressing the doublestrand RNA-specific ribonuclease gene PAC1. Trans. Res. 28, 129-140. doi: 10.1007/s11248-018-0108-8

Conflict of Interest: The authors declare that the research was conducted in the absence of any commercial or financial relationships that could be construed as a potential conflict of interest.

Copyright (c) 2020 Sorokan, Cherepanova, Burkhanova, Veselova, Rumyantsev, Alekseev, Mardanshin, Sarvarova, Khairullin, Benkovskaya and Maksimov. This is an open-access article distributed under the terms of the Creative Commons Attribution License (CC BY). The use, distribution or reproduction in other forums is permitted, provided the original author(s) and the copyright owner(s) are credited and that the original publication in this journal is cited, in accordance with accepted academic practice. No use, distribution or reproduction is permitted which does not comply with these terms. 